\title{
Toxo-pathological effects induced by urea in broiler chicks
}

\author{
K. A. Abdou ${ }^{\text {1* }}$ M. Mubarak ${ }^{2}$, A. A. Sharkawy ${ }^{3}$ \\ ${ }^{1}$ Department of Forensic Medicine and Toxicology, Faculty of Veterinary Medicine, Beni \\ Suef University, Egypt \\ ${ }^{2}$ Department of Pathology and Clinical Pathology, ${ }^{3}$ Deparment of Forensic Med. and \\ Toxicology, Faculty of Veterinary Medicine, Assiut University, Egypt
}

\begin{abstract}
Sixty, day-old, chicks were reared up to 3 weeks of age and then randomly divided into 4 equal groups ( 3 treated and one control group). Urea (46\% nitrogen) was added to the grower-finisher ration of the treated birds at levels of $1 \%, 3 \%$ and $5 \%$ (groups I, II \& III respectively). Feed and water were available ad libitum for all birds over the time of experiment. At days 7, 20 and 30 post exposure, 5 birds from each group were weighed, bled and sacrificed. All birds spontaneously died during the experiment were also necropsied. Haematological parameters (RBCs, WBCs counts, PCV and Hb), biochemical variables [urea, glucose, uric acid, alkaline phosphatase; (ALP) and lactate dehydrogenase; (LDH)] and body weight gain were assessed. The encountered pathological changes were described. The obtained results indicated that: (1) decrease in RBCs, WBCs counts, PCV and $\mathrm{Hb}$, (2) increase in ALP, LDH, urea and uric acid, while glucose level was decreased. (3) decrease in body weight gain in all treated birds. There were significant pathological changes in kidneys, heart, liver and lungs of the treated birds. It was concluded that addition of urea to poultry feeds to replace the more expensive protein-nitrogen has serious consequences which affect the health condition and weight gain of birds.
\end{abstract}

Urea is a white crystalline deliquescent solid substance which contains $42-45 \%$ nitrogen. Pure protein contains only $16 \%$ nitrogen, thus urea has the protein equivalent of $261-281 \%$ as to its nitrogen content (Kornegoy et al., 1970; Okumura et al.,1976).

Urea adulterated fish meal is used as economical protein source (Pervaz et al., 1993). Urea as a protein substitute does not enhance the value of conventional broiler diet (Kagan and Balloum, 1976b). The toxicity of urea occurs due to local and generalized effects of ammonia released in sufficient amounts. Haematological changes appear in the form of increased total erythrocytes, haemoglobin, packed cell volume and erythrocyte sedimentation rate. Differential leukocytic counts revealed lymphopenia, heterophilia and monocytosis in birds kept in diets containing urea (Chandra et al., 1984a). Urea ammoniated diets may be responsible for depression of growth, feed intake, efficiency of nutrient utilization. Decrease in total leukocytic count, low alanine aminotransferases activities

\footnotetext{
* Corresponding author. Tel.: +20 101906577;

fax: +20822327982 .

E-mail address: dr_kahaa@yahoo.com

(K. A. Abdou).
}

and increase in blood urea were observed in chicks fed urea containing diet (Nagalakshmi et al., 1999). Nephritis in poultry is caused either by nutritional imbalances or infectious agents. Diets containing urea is among nutritional factors. There were different renal and biochemical changes were observed in male chicks fed on urea containing diet including increased levels of glutamate oxaloacetate transaminase, glutamate pyruvate transaminase, uric acid and nonprotein nitrogen in serum. Increased in blood urea, hypoglycemia and decrease in hepatic glucose-6-phosphatase were also observed. These changes were directly correlated with the severity of nephritis and degenerative changes in various organs (Chandra et al., 1984b). Urea at $1.5-2 \%$ in mixed feed of layer has been held responsible for low egg production, leg weakness, paralysis and diarrhea with as high as $40 \%$ morbidity but low mortality (Gou, 1983). In spite of this feed adulteration that decreases costs greatly, the non-protein or non-essential nitrogen source has undesirable effects on the bird health (Pervaz et al., 1996). Due to variations in reports regarding the effects of urea administration in chicken, the present study was undertaken to elucidate the effects of 
Table (1): Basal composition of the diets used for feeding of experimental birds.

\begin{tabular}{lcc}
\hline & Starter & Grower-finisher \\
\hline I- Physical composition(\%) & 65.25 & 71.75 \\
Yellow corn, ground 3' & 19.72 & 15.77 \\
Soybean meal & 3.34 & 2.70 \\
Wheat bran & 4.00 & 4.00 \\
Ash meal & 6.50 & 4.50 \\
Meat meal & 0.60 & 0.72 \\
Limestone, ground & 0.00 & 0.10 \\
Dicalcium phosphate & 0.15 & 0.18 \\
Common salt & 0.11 & 0.02 \\
Dl-methionine & 0.08 & 0.01 \\
Lysine & 0.25 & 0.25 \\
Permix* & & \\
II- Chemical composition & & \\
ME, metabolizable energy(k cal/kg) & 2931 & 3011 \\
Crude protein (\%) & 21.07 & 18.81 \\
Calcium (\%) & 1.04 & 0.90 \\
Phosphorus (\%) & 0.49 & 0.41 \\
\end{tabular}

*Pfizer broiler premix: Furnishing the following ingredients per kg of feed (vit. A; 12000 IU, vit. D; 2000 $\mathrm{IU}$, vit. E; $10 \mathrm{mg}$, folic acid; $1 \mathrm{mg}$, niacin; 20, mg, pantothenic acid; $10 \mathrm{mg}$, vit. K; $2 \mathrm{mg}$, vit. Bl; $1 \mathrm{mg}$, vit. B2; $4 \mathrm{mg}$, vit. B6; $1.5 \mathrm{mg}$, vit. B12; $10 \mathrm{mg}$, biotin; $50 \mathrm{mg}$, iron; $30 \mathrm{mg}$, copper; $10 \mathrm{mg}$, zinc; $55 \mathrm{mg}$, manganese; $55 \mathrm{mg}$, iodine; $1 \mathrm{mg}$, selenium; $0.1 \mathrm{mg}$, choline chloride; $500 \mathrm{mg}$.

different urea levels (1, 3 and $5 \%)$ in broilers diet on the toxicological and pathological aspects.

\section{Material and Methods}

Birds. Sixty, day-old-broiler chicks obtained from a local hatchery were used. The birds were reared up to 20 days of age and during this period, feed (broiler starter ration containing no urea) and water were available ad libitum. The birds were vaccinated against Newcastle and infectious bursal disease viruses.

Diet. Basal composition of the diets used for feeding of experimental birds is presented in Table 1.

Experimental design. At 3 weeks of age, chicks were randomly divided into 4 equal groups (I, II, III and IV), 15 birds in each. The nitrogenous fertilizer containing $46 \%$ nitrogen which is available commercially was used as the urea source. Urea was added to the feed (growerfinisher ration) of the treated groups at the levels of 1\% (group I), 3\% (group II) and 5\% (group III) while the birds of group IV served as control and received feed without addition of urea. Table (1) shows the basal composition of the diets used in this study. Feed and water were available ad libitum for all birds along the time of experiment. At days 7,20 and 30 post-treatment,
5 birds from each group were weighed, bled and sacrificed. All birds spontaneously dead during the treatment were also necropsied.

Haematological and biochemical parameters. Blood samples obtained from all birds were drained into tubes with and without anticoagulant (EDTA $1 \mathrm{mg} / \mathrm{ml}$ blood). Erythrocytic and leucocytic counts were determined by using a haemocytometer according to (Natt and Herrick 1952). Packed cell volume (PCV) was determined using haematocrite tubes. Cyanmethaemoglobin method as described by (Benjamin, 1978) was used to estimate hemoglobin $(\mathrm{Hb})$. Serum harvested from the collected blood samples was used for estimation of the biochemical parameters. Uric acid was determined by kits (Diamond diagnostic) according to (Barham and Trinder, 1972). Urea level was estimated according to (Patton and Crouch, 1977) and glucose level was measured according to (Trinder, 1969) by using commercial kits (Diamond diagnostics). Lactate dehydrogenase (LDH) was measured by employing the diagnostic kits (Stanbio LDH, UV-rate, procedure No. 0940, USA) according to (Kachmar and Moss, 1976). Alkaline phosphatase (ALP) was determined colourimetrically as described (Kind and King 
1954 ) using commercial kits (Bio Merieux, France).

Histopathology. Samples from the kidneys, liver, lungs, heart, spleen, bursa of Fabricius, thymus and other organs and tissues from dead and necropsied birds were fixed in $10 \%$ neutralbuffered formalin. Tissue sample were then processed routinely for paraffin embedding technique. Embedded tissues were sectioned at $3 \mu \mathrm{m}$ and stained with hematoxylin and eosin (HE) (Bancroft and Stevens, 1982). Selected tissue sections were also stained with periodic acid Schiff (PAS).

Electron Microscopy. Immediately after necropsy, $1 \mathrm{~mm}$-cubs from kidneys, heart, liver and lung from treated (3\% and $5 \%$ groups) at all intervals and control birds were made and fixed in 3\% buffered glutaraldehyde. Tissue samples were then dehydrated in ascending grades of ethanol and embedded in Epon-812. Semi-thin sections were prepared for tissue orientation and accordingly thin sections were made and doubly stained with uranyl acetate and lead acetate. Stained sections were examined by transmission electron microscopy (JEOL, CX11) operated at 80 $\mathrm{Kv}$.

\section{Results \\ Clinical signs and mortality. Dullness} depression, excessive salivation (drooling of saliva), watery diarrhea, dyspnea (mouth breathing) and staggered gait were the clinical signs exhibited by all birds exposed to urea. However, signs were more severe in the birds of groups (II\& III) as compared to those of group I. These signs were observed as early as the second day after addition of urea. Feed intake of exposed birds was apparently decreased in comparison to control birds and in groups (II\& III). Water intake was increased in all exposed birds. No mortalities were recorded in birds received $1 \%$ urea (G I). Three birds in group II died on days 5 and 10 post-exposure. By day 10 post-exposure, all birds in group III died or were sacrificed for very bad health condition.

Haematology. RBCs and WBCs counts were comparatively decreased in all exposed birds. Although some fluctuations did exist, the decrements were dose and time related. Similarly, $\mathrm{Hb}$ and PCV values were decreased in dose and lime related patterns (Table 2)

Serum enzymes. Serum levels of ALP and LDH were significantly and consistently increased in direct proportional manner with dose and exposure time (Table 3 ).
Blood chemistry. Levels of urea and uric acid were steadily and significantly increased in all exposed birds. Significant decrements in glucose levels were recorded in all groups, except in group I at 7 days post-exposure (Table 3 ).

Body weight gain. Comparing with control birds, at any time post-exposure, the body weight gain of exposed birds was decreased. Body weight gain in birds of group III at 10 days postexposure was lower than that of control birds at 7 days post-exposure (Table 4 ).

Gross pathology. There were common gross lesions in the necropsied birds. Gross abnormalities noticed in birds of groups II and III were more severe than those encountered in birds at group I. Livers were swollen, congested, friable and mottled in some cases. Congestion and edema of lungs were apparent. Kidneys were congested, swollen and had clear tubular markings. Catarrhal gastroenteritis, including severe catarrhal duodenitis, was a common finding. Spleens were enlarged and congested. Body musculature was congested in some cases. Swelling and edema in bursa of Fabricius and thymus were infrequent. Dead birds in group III showed marked distention of ureters with urates and urate deposits in the kidney as well as allover the peritoneal surfaces of liver.

Histopathology. Noticeable histological changes were observed in the kidney, liver, lung and heart. Increased severity of these changes was dose and time related. The prominent changes were that noticed in groups II \& III at least in two intervals (20 and 30 days). The severity of changes in group III at 10 days post-exposure was similar to that noticed in group II at 20 and 30 days post-exposure. Kidney at 7 days postexposure showed tubular cell degeneration(vacuolar degeneration) and edema of the interstitial tissue. Hyaline casts and urate material were noticed in the lumen of cortical and medullary tubules. Mild proliferative glomerulitis was also seen. At 20 days postexposure, the tubular necrosis was observed. Renal interstitum showed edema, hemorrhage, heterophil cell infiltration and increased lymphoid cell aggregates. Interstitial urate deposits (Fig.1) associated with tubular necrosis and proliferative glomerulitis were also noticed. Similar but more severe renal histological changes were detected at 30 days post-exposure. Multi-focal interstitial lymphoid cell aggregates associated with tubular destruction were noticed. Picture of proliferative glomerulitis was more 
Table (2): Haematological pictures of broiler chicks exposed to urea.

\begin{tabular}{|c|c|c|c|c|c|}
\hline $\begin{array}{c}\text { Exposure } \\
\text { time(days) } \\
\end{array}$ & animals & $\begin{array}{c}\text { RBCs } \\
\left(\mathrm{x}^{6} 0^{6} / \mathrm{ml}\right)\end{array}$ & $\begin{array}{c}\text { WBCs } \\
\left(\mathrm{x}^{3} 0^{3} / \mathrm{ml}\right)\end{array}$ & $\operatorname{PCV}(\%)$ & $\mathrm{Hb}(\mathrm{g} / \mathrm{dl})$ \\
\hline \multirow{4}{*}{7} & G I & $1.670 \pm 0.115$ & $30.11 \pm 1.11$ & $27.90 \pm 0.87$ & $8.870 \pm 0.321$ \\
\hline & G II & $1.515 \pm 0.089 *$ & $29.00 \pm 2.43$ & $27.10 \pm 0.53$ & $8.700 \pm 0.340$ \\
\hline & G III & $1.315 \pm 0.059 *$ & $24.80 \pm 2.85$ & $26.30 \pm 0.95$ & $8.550 \pm 0.710$ \\
\hline & $\begin{array}{c}\text { G IV } \\
\text { (Control) }\end{array}$ & $1.890 \pm 0.058$ & $32.20 \pm 2.25$ & $28.70 \pm 1.03$ & $9.150 \pm 0.175$ \\
\hline \multirow{6}{*}{20} & G I & $1.630 \pm 0.135$ & $31.36 \pm 0.53 *$ & $28.10 \pm 0.90$ & $8.600 \pm 0.490$ \\
\hline & G II & $1.490 \pm 0.061^{*}$ & $30.40 \pm 1.51^{*}$ & $27.00 \pm 0.55^{*}$ & $8.500 \pm 0.316$ \\
\hline & G III & $1.417 \pm 0.048 *$ & $31.20 \pm 2.85$ & $26.10 \pm 0.57^{*}$ & $7.450 \pm 0.326^{*}$ \\
\hline & $\begin{array}{c}\text { G IV } \\
\text { (Control) }\end{array}$ & $1.960 \pm 0.083$ & $34.70 \pm 0.97$ & $29.20 \pm 0.51$ & $9.550 \pm 0.458$ \\
\hline & G I & $1.850 \pm 0.780$ & $32.13 \pm 0.18^{*}$ & $29.71 \pm 1.03$ & $8.550 \pm 1.55$ \\
\hline & G II & $1.550 \pm 0.195$ & $31.30 \pm 1.06^{*}$ & $28.13 \pm 0.97 *$ & $8.450 \pm 0.295^{*}$ \\
\hline \multirow[b]{2}{*}{30} & G III & ND & ND & ND & ND \\
\hline & $\begin{array}{c}\text { G IV } \\
\text { (Control) }\end{array}$ & $2.025 \pm 0.790$ & $36.90 \pm 1.20$ & $31.20 \pm 0.15$ & $9.650 \pm 0.395$ \\
\hline $\begin{array}{l}\text { - Values ar } \\
\mathrm{ND}=\mathrm{No}\end{array}$ & $\begin{array}{l}=\text { S.E.M } \\
\text { ned }\end{array}$ & & at at $p \leq 0.05$ & & \\
\hline
\end{tabular}

Table (3): Biochemical changes induced in broiler chicks exposed to urea.

\begin{tabular}{|c|c|c|c|c|c|c|}
\hline $\begin{array}{c}\text { Exposure time } \\
\text { (days) }\end{array}$ & Animals & Urea(mg/dl) & $\begin{array}{c}\text { Uric acid } \\
(\mathrm{mg} / \mathrm{dl})\end{array}$ & $\begin{array}{l}\text { Glucose } \\
(\mathrm{mg} / \mathrm{dl})\end{array}$ & $\mathbf{A L P}(\mathbf{U} / \mathbf{L})$ & $\mathbf{L D H}(\mathbf{U} / \mathbf{L})$ \\
\hline \multirow{4}{*}{7} & G I & $\begin{array}{r}45.244 \pm \\
5.380^{*}\end{array}$ & $\begin{array}{c}21.946 \pm \\
1.605^{*}\end{array}$ & $\begin{array}{c}82.000 \pm \\
4.988\end{array}$ & $\begin{array}{c}97.826 \pm \\
5.785\end{array}$ & $\begin{array}{c}241.127 \pm \\
10.957^{*}\end{array}$ \\
\hline & G II & $\begin{array}{r}123.431 \pm \\
7.003 *\end{array}$ & $\begin{array}{c}26.866 \pm \\
1601 *\end{array}$ & $\begin{array}{c}70.000 \pm \\
3.294^{*}\end{array}$ & $\begin{array}{c}110.270 \pm \\
6.161 *\end{array}$ & $\begin{array}{c}274.226 \pm \\
11.223 *\end{array}$ \\
\hline & G III & $\begin{array}{c}290.440 \pm \\
8318 *\end{array}$ & $\begin{array}{l}47.260 \pm \\
1.493 *\end{array}$ & $\begin{array}{l}65.721 \pm \\
5244 *\end{array}$ & $\begin{array}{c}133.271 \pm \\
8160 *\end{array}$ & $\begin{array}{c}480.596 \pm \\
6.739 *\end{array}$ \\
\hline & $\begin{array}{c}\text { G IV } \\
\text { (Control) }\end{array}$ & $11.029 \pm 1.726$ & $\begin{array}{c}10.938 \pm \\
0.425\end{array}$ & $\begin{array}{c}84.008 \pm \\
2.210\end{array}$ & $\begin{array}{c}92.568 \pm \\
4.231\end{array}$ & $\begin{array}{c}39.611 \pm \\
0.372\end{array}$ \\
\hline \multirow{5}{*}{20} & G I & $\begin{array}{c}186.176 \\
8.956^{*}\end{array}$ & $\begin{array}{c}41.734 \pm \\
1.693^{*}\end{array}$ & $\begin{array}{c}77.265 \pm \\
8.979^{*}\end{array}$ & $\begin{array}{c}102.113 \pm \\
8.777\end{array}$ & $\begin{array}{c}250.363 \pm \\
10.364^{*}\end{array}$ \\
\hline & G II & $\begin{array}{l}238.038 \pm \\
25.613^{*}\end{array}$ & $\begin{array}{l}47.114 \pm \\
2.255^{*}\end{array}$ & $\begin{array}{c}62.107 \pm \\
6.647^{*}\end{array}$ & $\begin{array}{c}125.853 \pm \\
6.111^{*}\end{array}$ & $\begin{array}{c}373.898 \pm \\
16.166^{*}\end{array}$ \\
\hline & G III & $\begin{array}{c}471.176 \quad \pm \\
15.532^{*}\end{array}$ & $\begin{array}{c}55.008 \pm \\
2.833^{*}\end{array}$ & $\begin{array}{c}48.807 \pm \\
4.312^{*}\end{array}$ & $\begin{array}{c}158.360 \pm \\
12.074^{*}\end{array}$ & $\begin{array}{c}495.190 \pm \\
14.802 *\end{array}$ \\
\hline & $\begin{array}{c}\text { G IV } \\
\text { (Control) }\end{array}$ & $\begin{array}{c}14.705 \\
1.780\end{array}$ & $\begin{array}{l}13.566 \pm \\
1.013\end{array}$ & $\begin{array}{c}103.842 \pm \\
6.125\end{array}$ & $\begin{array}{c}90.104 \pm \\
6.196\end{array}$ & $\begin{array}{l}46.425 \pm \\
5.596\end{array}$ \\
\hline & G I & $\begin{array}{c}218.723 \pm \\
13.842^{*}\end{array}$ & $\begin{array}{c}47.645 \pm \\
1.189^{*}\end{array}$ & $\begin{array}{l}45.264 \pm \\
2.979 *\end{array}$ & $\begin{array}{c}112.744 \pm \\
8.334\end{array}$ & $\begin{array}{c}306.923 \pm \\
20.969^{*}\end{array}$ \\
\hline \multirow{3}{*}{30} & G II & $\begin{array}{c}543.707 \pm \\
27.002 *\end{array}$ & $\begin{array}{l}59.477 \pm \\
0.611^{*}\end{array}$ & $\begin{array}{c}55.651 \pm \\
7.788^{*}\end{array}$ & $\begin{array}{c}134.892 \pm \\
7.483^{*}\end{array}$ & $\begin{array}{c}406.176 \pm \\
13.908^{*}\end{array}$ \\
\hline & G III & ND & ND & ND & ND & ND \\
\hline & $\begin{array}{c}\text { G IV } \\
\text { (Control) }\end{array}$ & $\begin{array}{c}18.569 \\
0.802\end{array}$ & $\begin{array}{c}15.938 \pm \\
0.251\end{array}$ & $\begin{array}{c}114.226 \pm \\
8.094\end{array}$ & $\begin{array}{c}91.089 \pm \\
5.872\end{array}$ & $\begin{array}{c}41.425 \pm \\
1.802\end{array}$ \\
\hline
\end{tabular}

-Values are mean \pm S.E.M.

- ND = Not determined
$-5 \%$ in 30 days was measured at 10 days post-exposure.

*Significant at $\mathrm{p} \leq 0.05$ 


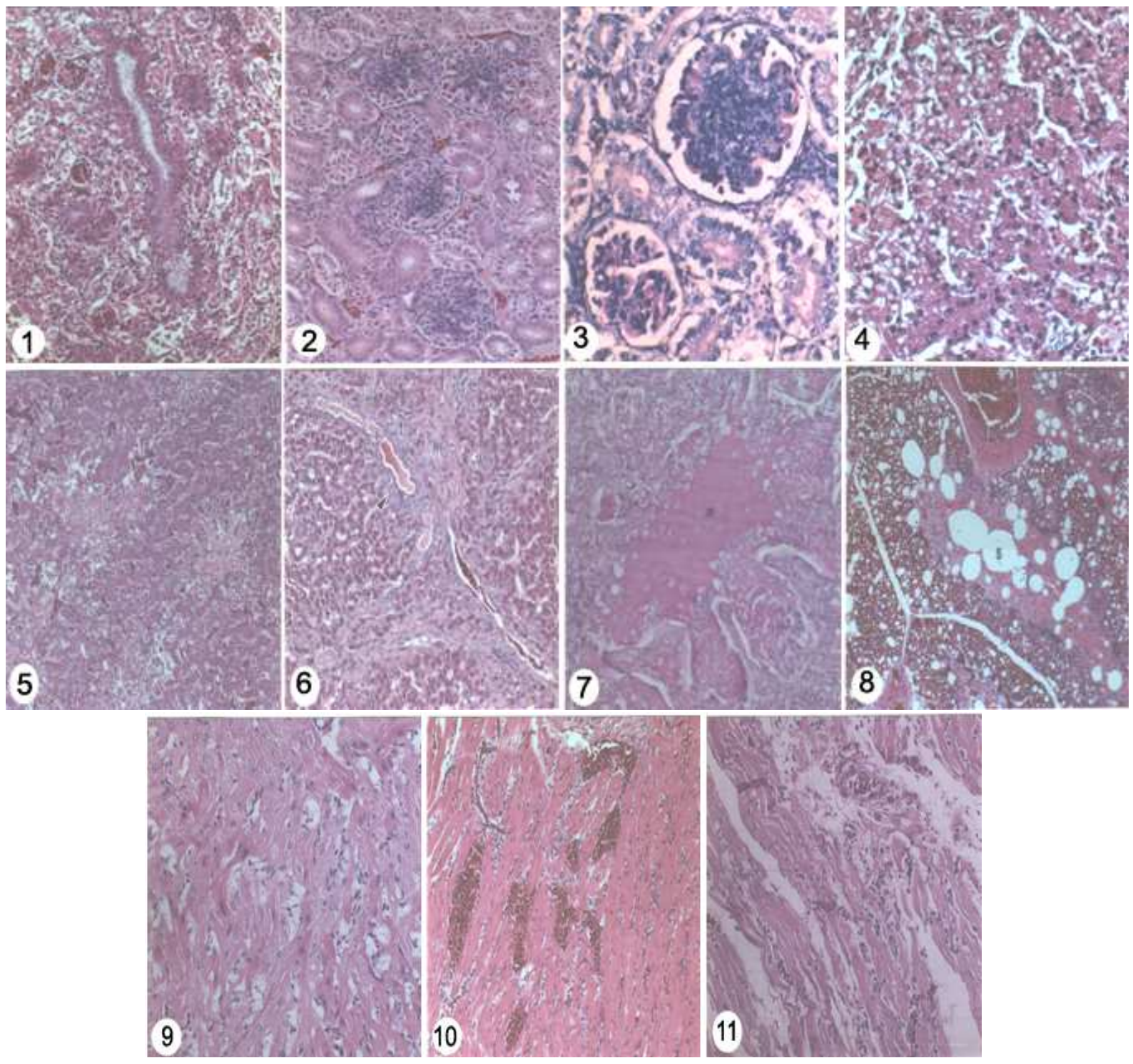

Fig. (1): Interstitial crystallized urate deposits associated with tubular necrosis in the kidney of urea-exposed chicken. Group II, 20 days exposure. H.E. X 125.

Fig. (2): Kidney showing proliferated glomeruli. The glomerular proliferation is mainly constituted by mesangial cells. Visceral epithelial cells are swollen and nearly adhered to parietal epithelium. Group II, 20 days exposure. H.E. X 125. Fig. (3): Thickened glomerular basement membrane (GBMs) (arrow) accompanied with mesangial cell proliferation in the kidney of urea-exposed birds. Group II, 30 days exposure. PAS. X 320.

Fig. (4): Liver showing fatty vacuolization of hepatocytes. Group II, 20 days exposure. H.E. X 200

Fig. (5): Multifocal hyaline necrosis (arrow) in the liver of chicken exposed to $3 \%$ urea for 30 days.

Fig. (6): Proliferated bile duct epithelium (arrow) in the liver. The ducts are filled with bile. Group II, 30 days exposure.

H.E. X 200.

Fig. (7): Parabronchus filled with edematous PAS-positive material (m). The parabronchus matrix is collapsed. Group II, 7 days exposure. PAS. X 200.

Fig. (8): Lung showing collapsed parabronchus (p). The parabronchus atria are adhered to form rounded spaces (S). Group II, 30 days exposure. H.E. X 200.

Fig. (9): Granular degeneration and vacuolization of myofiber cytoplasm (sarcoplasm). The degenerated myofibers are disorganized. Heart of urea-exposed chicken. Group II, 20 days exposure. H \& E. X 125.

Fig. (10): Focal haemorrhages in the myocardium. Group II, 20 days exposure.

H.E. X 125.

Fig. (11): Disarraged thin myofibers (arrow) associated, with focal myolysis in myocardium. Group II, 30 days exposure. H.E. X 125. 

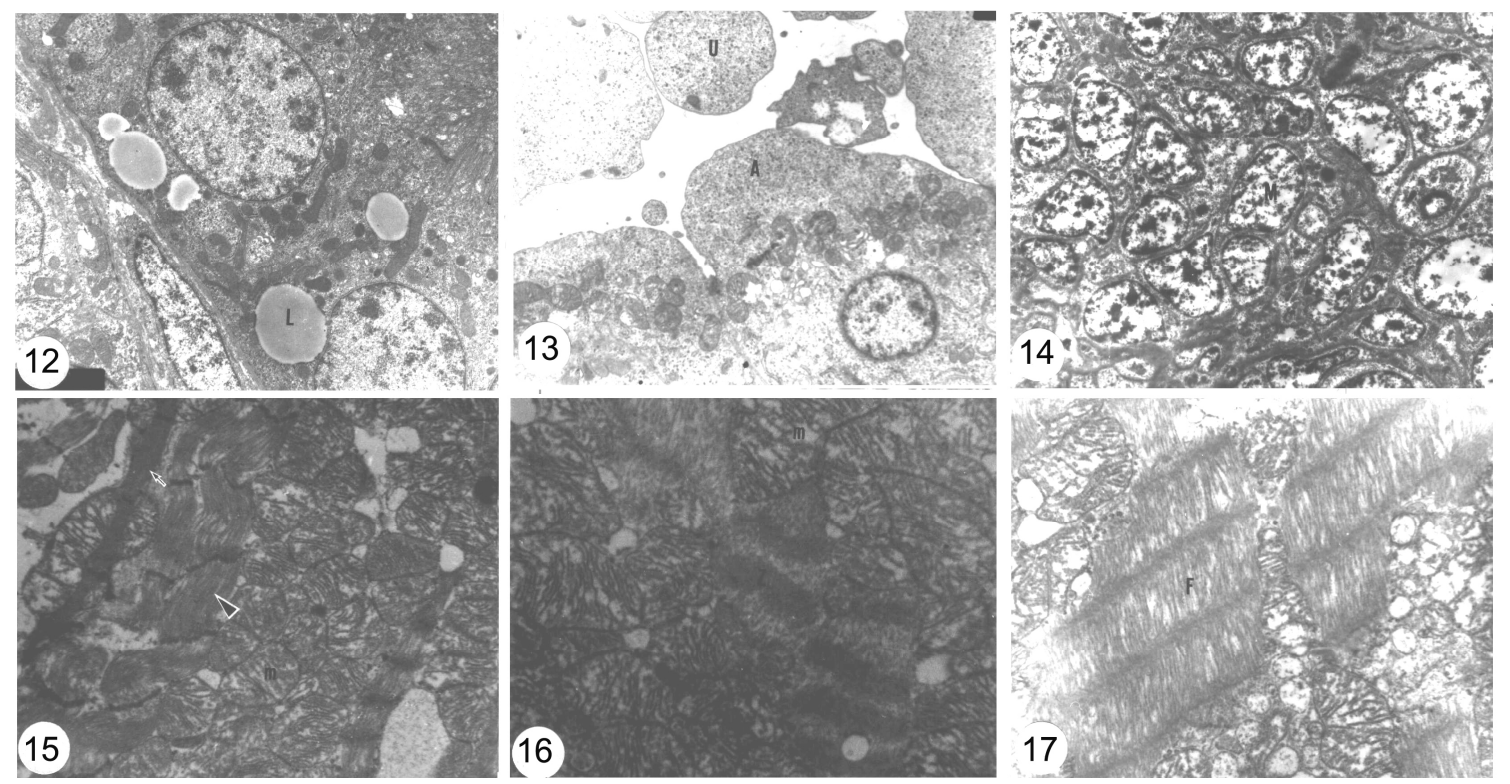

Fig. (12): Fat droplets (arrow) of moderate electron-density in the basal cytoplasm of proximal tubular cells. Group II, 20 days exposure.TEM. X 4700.

Fig. (13): Collecting tubule containing amorphous granular urate material (U). The apical cytoplasm (A) of tubular cells is blebbed. Group II, 20 days exposure.TEM. X4500.

Fig. (14): Proliferated mesangial cells (M) filling the glomerular space in the kidney. Group II, 20 days exposure. TEM. X 7500.

Fig. (15): Thin (arrow) and thick (arrowhead) myofibers in the myocardium. The mitochondria (m) are hyperplastic. Group II, 20 days exposure TEM. X 7500.

Fig. (16): Thick and approximated Z-band (arrow) in the myocardium. The fibers are disarranged. The cristae of mitochondria (m) are disoriented. Group II, 20 days exposure. TEM. X 10,000.

Fig. (17): Myofibers (F) showing disarray and lysis of myofibrils which obvious loss of banding. Group II, 20 days exposure. TEM. X 8000 .

evident and involved marked mesangial and epithelial cell proliferation of affected glomeruli (Fig. 2). Some cases had thickened glomerular basement membrane (Fig.3)

Hepatic histological changes at 7 days postexposure in groups II \& III showed hepatocellular degeneration (cell swelling and hydropic degeneration). Perivascular edema in portal areas and endothelial cell degeneration of portal blood vessel were also found. At 20 days post-exposure (group II), fatty change of hepatocytes associated with hyaline necrosis were noticed (Fig. 4). Edematous changes were more obvious and hemorrhages were more frequent. Lymphoid cell aggregates were multifocal. Advential and perivascular edema was more remarkable in the portal areas. Endothelial cells of portal vessels were degenerated and proliferative. At 30 days post-exposure in group II (3\% urea), hepatocellular degeneration was more diffuse and associated with multi-focal necrosis (Fig. 5). Haemorrhages were larger and frequent. Kupffer cells were hypertrophoid. Endothelial cells lining the portal blood vessels were more proliferative and projected into the vascular lumina. In some cases, bile ducts were filled and bile duct epithelium was proliferated (Fig. 6).

Pulmonary changes at 7 days post-exposure in groups II \& III included congestion of vasculature, perivascular edema and haemorrhages and acute catarrhal bronchitis with accumulation of mucus in the bronchial lumina. Edematous changes of pulmonary tissues were more noticeable at 20 days post-exposure in group II with the presence of eosinophilic material in the parabronchial lumina (Fig. 7). Haemorrhages were noticed at perivascular locations and also within the parabronchial matrices. Parabronchial epithelium was proliferated and parabronchial muscles were hypertrophoid. Similar but more severe pulmonary changes were noticed at 30 days postexposure. Parabronchial collapse associated with hypertrophy of parabronchial muscles were frequent (Fig. 8).

Myocardial changes at 7 days post-exposure in groups II \& III included edema between 
Table (4): Body weight gain of birds received different levels of urea at different intervals.

\begin{tabular}{lccc}
\hline \multirow{2}{*}{ Animals } & \multicolumn{3}{c}{ Time post-exposure } \\
\cline { 2 - 4 } & $\mathbf{7}$ days & $\mathbf{2 0}$ days & $\mathbf{3 0 \text { days }}$ \\
\hline G I & 35.593 & 44.067 & 67.796 \\
G II & 19.491 & 10.169 & 5.084 \\
G III & 15.254 & -3.389 & $\mathrm{ND}$ \\
G IV & 45.762 & 103.389 & 167.796 \\
(Control) & & & \\
\hline
\end{tabular}

Table (5): Scoring for the main histological changes of liver, heart, lung and kidneys of birds received $3 \%$ urea (G II) in their feed.

\begin{tabular}{|c|c|c|c|}
\hline \multirow[b]{2}{*}{ Organ } & \multicolumn{3}{|c|}{ Time post-exposure } \\
\hline & $\begin{array}{c}7 \\
\text { days }\end{array}$ & $\begin{array}{c}20 \\
\text { days }\end{array}$ & $\begin{array}{c}30 \\
\text { days }\end{array}$ \\
\hline \multicolumn{4}{|l|}{ Liver: } \\
\hline - Cell swelling & ++ & +++ & +++ \\
\hline - Vacuolar degeneration & - & ++ & +++ \\
\hline - Fatty change & - & ++ & +++ \\
\hline - Edema & + & +++ & +++ \\
\hline - Haemorrhage & + & ++ & +++ \\
\hline \multicolumn{4}{|l|}{ Heart: } \\
\hline -Myodegeneration & + & ++ & +++ \\
\hline - Myolysis & - & ++ & ++ \\
\hline - Edema & ++ & +++ & +++ \\
\hline - Haemorrhage & + & ++ & +++ \\
\hline \multicolumn{4}{|l|}{ Lung: } \\
\hline - Congestion & + & ++ & +++ \\
\hline - Perivascular edema & + & ++ & +++ \\
\hline - Parabronchial edema & - & + & ++ \\
\hline - Catarrhal bronchitis & - & ++ & ++++ \\
\hline \multicolumn{4}{|l|}{ Kidney: } \\
\hline - Tubular cell degeneration & + & ++ & ++++ \\
\hline - Urate deposits & + & ++ & +++ \\
\hline - Proliferative glomerulitis & - & + & +++ \\
\hline
\end{tabular}

myofibers which were degenerated. Myofiber sarcoplasm was pale and vacuolated. Myocardial tissues also revealed minute focal haemorrhages. Granular degeneration of myofibers, sarcoplasm (Fig.9), edema separating myofibers, perivascular edema, larger haemorrhagic foci (Fig. 10) and focal myolysis with disintegration of myofiber sarcoplasm were noticed at 20 days post-exposure in group II .Similar findings were observed at 30 days post-exposure group II with more frequent myocardial haemorrhages. There were many thin and lysed myofibers (Fig. 11) which had pyknotic nuclei. Myocardial blood vessels showed endothelial degenerative, proliferative and hypertrophic changes.
Subendocardial edema was observed in many cases. Intestinal tract of exposed birds showed picture of acute catarrhal changes with hypertrophy of goblet cells and accumulation of mucus over the intestinal mucosa. Other organs (spleen, thymus and bursa of Fabricius) and tissues showed edematous changes in their parenchyma. Brain tissues of exposed birds especially those in groups II \& III revealed neuronal degeneration, pericellular and perivascular edema. Occasional focal gliosis was also observed.

Electron microscopy. Kidney samples taken at 20 and 30 days post-exposure in group II showed vacuolation in the apical cytoplasm of tubular cells, blebbing and loss of microvilli. In the basal cytoplasm of renal tubular cells especially in the proximal tubules, fat droplets of moderate electron density were noticed (Fig. 12). Urate deposits, seen as granular material, were found in the tubular lumina accompanied with destruction of the microvillar brush border (Fig. 3 ). Many glomeruli had proliferative mesangial cells which filled the glomerular spaces (Fig. 14). Nuclei of the proliferative mesangial cells were pleomorphic and had dense chromatin clumps) heterochromatin). In some of the proliferated glomeruli, glomerular basement membranes were locally or diffusely thickened with swelling of podocytes which lost their foot processes. Examined myocardial tissues revealed variation in the size of myofibers with the presence of thin and thick fibers at 20 and 30 days post-exposure in group II (Fig 15). Thin myofibers were more electron dense. Nuclei of myofibers varied in size. Banding (cross striation) of myofibers was irregular with the presence of thick Z-bands. Approximation of thickened Z-bands was detected in some myofibers (hypercontracted myofibers) (Fig. 16). Many myofibers showed disarray or lysis of myofibrils with indistinction of the sarcomere pattern (Fig. 17). The disarrayed or lysed myofibers had markedly decreased electron density. Mitochondrial hyperplasia was a distinct feature in some cases. The profiles of mitochondria were abnormal with the presence of swollen and elongated mitochondria. Mitochondrial cristae were deteriorated and there were matrical densities. Glycogen rosettes were also found between myofibers. The examined liver samples at 20 and 30 days post-exposure (group II) showed many pyknotic nuclei which had highly condensed chromatin. 
There were many mitochondrial-RER associations. Mitochondria in hepatocyte cytoplasm were hyperplastic and their cristae were abnormal. Glycogen content of hepatocytes was sparse. Many hepatocytes had disrupted and deteriorated cell organelles, with indistinction of cellular outlines. Varied sized cytoplasmic lipid droplets were frequently seen in some cases. All the examined lung tissues at all intervals (groups II \& III) disclosed distention of blood capillaries which had markedly swollen endothelial cells. The latter cells had surface blobbing and dilated profiles of cell organelles, on the other, side of the basement membrane separating air and blood capillaries. Pneumocytes were swollen and had cytoplasmic vacuoles and lamellar structures.

\section{Discussion}

In the present study, birds were exposed to different levels of urea $(1 \%, 3 \%$ and $5 \%)$ within feed. This was done to elucidate the deleterious effect of adulteration of broiler rations by addition of urea to increase the dietary protein content.

Birds in this study exhibited clinical signs of toxicity similar to those reported in large animals (Gou, 1983). In ruminants, clinical signs of toxicity were attributed to increased blood ammonia level since these animals have urease enzyme (ammonia- generating enzyme) which converts urea to ammonia (Bartick and Piskac, 1981; Gornall, 1980). In the present work especially in groups II \& III, body weight decreased greatly as compared with control birds. Marked decrease in body weight was another indication to emaciation of the exposed birds. In addition, this reflected low feed conversion rate and may in part be attributed to decreased feed intake exhibited by these birds. Undoubtedly, body weight gain is a critical point in evaluation of broiler farm profits and poor weight gain means economical losses. All haematological parameters measured in the present work including RBCs, WBCs counts, $\mathrm{PCV}$ and $\mathrm{Hb}$ were decreased and significant decrements were recorded in groups II \& III. Pervaz et al., (1996) recorded lowered haematological parameters in urea intoxicated birds and attributed the decreased RBCs count to lowered erythropoietin factor due to renal and hepatic damage. Chandra et al., (1984c) incriminated hypoglycemia and the associated decreased metabolic activity in decreasing RBCs count through shortening of RBCs life span. On contrast, Chandra et al. (1984b) reported increased erythropoietic parameters in birds received ration containing urea. However, those authors interpreted that increments were untrue and probably related to fluid loss with diarrhea (relative increments). We assume that decrements of hematological parameters in our cases were related to depressed haemopoiesis caused by increasing substances such as urea and uric acid. Currently, levels of urea and uric acid were found significantly increased in a dose related pattern especially in groups II \& III. Increased level of circulating urea may be due to direct intestinal absorption of dietary urea (Chandra et al., 1984c; Karasawa et al, 1994). The elevation of blood ammonia due to conversion of urea to ammonia in this study continued. This may be related to the fact that the rate of ammonia production is more than utilization and detoxification (Bartik and Piskac, 1981). The latter authors added that blood urea is also increased in urea- intoxicated animals due to subsequent activation of a ureosynthetic cycle in the liver. In chickens, the ureolytic activity (ammoniogenesis) chiefly takes place in caecum where urease enzyme is localized (Lee, 1977; Karasawa et al., 1988a, b, 1993,1994). In birds the intestinal ureolytic activity is also very low and urea is completely absorbed without concomitant increase in blood ammonia (Kagan and Balloun, 1976b). Hence, we focused on measuring blood urea as a more reliable parameter of toxicity in chickens.

The dose related increase in uric acid (hyperuricaemia) recorded here was probably the result of increased biosynthesis or decreased renal excretion of uric acid as suggested by (Chandra et al., 1984c). Renal damage demonstrated here is known to be associate with increased blood levels of urea and uric acid (Chaudhari and Kaul, 1996). In the presence of increased blood urea level, abnormal catabolic activities may exist and hyperuricaemia may be arised from catabolism of endogenous protein (Sykes, 1971). More simply, in dehydrated birds and due to diarrhea, it was found that the highly efficient renal tubular reabsorption resulted in increased blood urea and uric acid (Siller, 1981).

In the present work, hypoglycaemia was recorded in all urea-exposed birds. In similar cases, hypoglycaemia was ascribed to intestinal malabsorption or renal malreabsorption of glucose (Chandra et al., 1984c). Intestinal and renal histological changes noticed in our birds may substantiate this suggestion.

The exposed birds had significantly increased serum levels of ALP and LDH. In 
general, increased serum levels of these enzymes indicate leakage from the damaged parenchymatous organs (Coles, 1986; Thomson, 1984). Increased LDH is related to myopathies which involves myocardiopathy (Kramer, 1989). The histological changes described here may support the presumption that these enzymes were released from the damaged parenchymatous organs.

Similar gross pathological changes to those observed here also reported in large animals intoxicated by urea (Bartik and Piskac, 1981). Microscopically, we observed both degenerative and inflammatory changes in parenchymatous organs. Increased blood levels of urea and uric acid were most probably the cause of these pathological changes. It was stated that increased nitrogen intake (nitrogen overload) as in urea toxicity, may result in toxic degenerative changes in various tissues (Chandra et al., 1984a, 1994c). Moreover, ammonia arised at caecum due to the action of caecal urease on urea, may be absorbed and carried to liver which is thus subjected to the damaging effect of ammonia.

The illustrated renal damage in our cases was probably the result of the injurious effects of uric acids overload (hyperuricaemia). In turn, renal tubular damage leads to underexcretion of uric acid and hyperuricaemia is accentuated and thus vicious cycle is developed. Picture of glomerulonephritis in our intoxicated cases was likely the sequence of urea and ammoniainduced damage at the level of glomerular filtration. In this respect, increased nitrogen intake is among causes of non-infectious nephritis in birds (Chandra et al., 1984c). The observed interstitial nephritis was subsequent to urate deposition in the renal interstitium after damage of the tubular structure. Pulmonary changes seen in our cases were possibly the result of the damaging effect of circulating urea on the vascular walls. Similarly, myocardial changes were probably urea-induced. Comparable pathological changes were reported in urea poisoning of large animals (Kim et al., 1982).

In the view of the encountered pathological changes, death of intoxicated birds in the present study may be attributed to renal, respiratory and cardiac failures (or one of them). Urea-poisoned ruminants were died for the same reasons (Itabisashi, 1977).

The obtained data point to the failure of broiler chickens to utilize urea (non- protein nitrogen) as a partial substitute for protein ruminants can do (Swift et al., 1947; Morrison, 1959; Visek, 1972; Abdel-hafez and Tony, 1974; Perry et al., 1976). This failure was also apparent even at low doses of dietary urea (group I) used in the present work. Previous studies (Korregoy et al., 1970; Kagan and Balloun, 1976a; Okumura et al., 1976, 1979) pointed to inability of chickens to utilize dietary urea in synthesis of amino acids. Urea as a dietary component provides no energy, minerals or vitamins (Loosli and McDonald, 1968).

The present data obviously point to the serious effects of using urea as a source of dietary protein. Presently, urea toxicity affected markedly health condition of the experimental birds and induced evident biochemical and pathological changes in various organs and tissues. In conclusion, addition of urea to poultry feeds to replace the more expensive proteinnitrogen has serious sequences which affect the bird health condition and its weight gain.

\section{References}

Abdel-Hafez, H. M. and Tony, S. M. (1974): Effect of urea and free sulfur on digestibility in sheep. Assiut Vet. Med. J., 4:101-109.

Bancroft, D. and Stevens, A. (1982): Theory and Practice of histological techniques, $2^{\text {nd }}$ ed. Churchil Livingstone (Edinburgh, London, Melbourne).

Barham, D. and Trinder, P. (1972): Analyst, 97:142-145. Bartik, M. and Piskac, A. (1981): Veterinary Toxicology, Elsevier Scientific Publishing Company (Amsterdam, Oxford, New York).

Benjamin, M. M. (1978): Outline of Veterinary Clinical Pathology. $3^{\text {rd }}$ ed., Iowa State University Press, Ames, Iowa.

Chandra, M.; Singh, S.; Gupta, P.P. and Ahuja, S. P. (1984a): Comparative pathogenesis of nephritis in poultry induced by high protein, high calcium, urea and vitamin A deficient diets. Acta Vet., 34: 113-134.

Chandra, M.; Singh, B.; Singh, N. and Ahuja, S. P. (1984b): Hematological changes in nephritis induced by diets high in protein, high calcium containing urea or deficient in vitamin A. Poult. Sci., 63: 710-716.

Chandra, M.; Sigh, B.; Soni, G. L. and Ahuja, S. P. (1984c): Renal and biochemical Hematological changes in nephritis induced by diets high in protein, high calcium, urea-containing and vitamin A. deficient diet. Avian Dis., 28:1-11.

Chaudhari, G. R., and Kaul L. (1996): Effect of castor meal feeding on serum and uric acid concentration in white Leghorn cockerels. Ind. J. Env. Toxicol., 1: 45-47 .

Coles, E. H., (1986): Veterinary Clinical Pathology. $3^{\text {rd }}$ ed., W. B. Saunders Company (Philadelphia), pp. 89-90.

Gornall, A. G. (1980): Disorders of amino acid and protein metabolism. In: Applied Biochemistry of Clinical Disorders. Haper and Row Publishers Inc. (Virginia, Avenue, Maryland), pp. 323.

Gou, X. D. ( 1983 ) : Preliminary observation on urea poisoning in chickens. Chin. J. Vet. Med., 9: 36-37. Itabisashi, T. (1977): Electrocardiographic observation on 
goats with urea-ammonia poisoning and consideration in the main cause of death. Nat. Inst. Anim. Health, 17: 151162

Kachmar, J. F, and Moss, D. W. (1976): In fundamentals of Clinical Chemistry, $2^{\text {nd }}$ ed., N.W. Tietz (ed). W. B. Saunders, Philadelphia, pp. 652.

Kagan, A. and Balloun, S. L. (1976a): L-Aspartic acid and urea supplementation of low protein layer diets. Br. Poultry Sci., 17: 371-377.

Kagan, A. and Balloun, S. L. (1976b): Urea and aspartic acid supplementation in broiler diets. Br. Poultry Sci., 17: 403-413.

Karasawa, Y.; Kawai, H. and Hosono, A. (1988 a): Ammonia production from amino acids and urea in the caecal contents of the chicken. Comp. Biochem. Physiol . 90B: 205-207.

Karasawa, Y.; Okumoto, M. and Kawai, H. (1988 b): Ammonia production from uric acid and its absorption from the caecum of the cockerel. Br. Poultry Sci., 29: 119-124.

Karasawa, Y.; Ono, T. and Koh, K. (1994): Inhibitory effect of penicillin on caecal urease activity in chicken fed on a low protein diet plus urea. Br. Poult. Sci., 35:151- 160. Karasawa, Y.; Umemoto, M. and Koh, K. (1993): Effect of dietary protein and urea on in vivo caecal ammonia production from urea and uric acid in cockerel. Br. Poult. Sci., 34: 711-714.

Kim, S. B.; Chung, U. I.; Kirn, S. B. and Chung, U. I. (1982): Pathological studies on urea poisoning in dairy goats. Korean J. Vet. Res., 22: 233-237.

Kind, P. R. N. and King, E. G. (1954): J. Clin. Pathol., 7: 322 .

Kornegoy, E. T.; Mosanghini, V. and Snee, R. D. (1970): Urea and amino acid supplementation of swine diets. J. Nutr., 10: 330-340.

Kramer, J. W. (1989): Clinical enzymology. In: Clinical Biochemistry of Domestic Animals. J. J. Kaneko (ed.), $4^{\text {th }}$ ed., Academic Press (San Diego, New York), pp. 338-360

Lee, D. J. N. (1977): Urease activity in the digestive tract of the chick and its role in the utilization of urea as a source of non-amino nitrogen. Br. Poult. Sci., 18: 449- 458.

Loosli, J. K. and McDonald, J. W. (1968): Non-protein nitrogen in the nutrition of ruminants. FAO Agric. Studies. No. 75. Rome.
Morrison, H. B. ( 1959 ) : Feeds and feeding. $22^{\text {nd }}$ ed. Morrison Publishing Company (Clinton, Iowa), pp. 774.

Nagalakshmi, D.; Sastru, V.R.; Katiyar, R.C.; Agrawal, D.K. and Verma, S.V. (1999): Performance of broiler chicks fed on diets containing urea ammoniated neem (Azadirachta indical) kernel cake. Br. Poult. Sci., 40 (1): 77-83

Natt, M. P., and Herrick, C. A. (1952): a new diluent for counting the erythrocytes and leukocytes for the chicken. Poult. Sci., 31: 735-737.

Okumura, J.; Hewitt, D.; Salter, D. N. and Coates, M. E. (1976): The role of gut microflora in the utilization of dietary urea by the chicks. Br. J. Nutr., 36: 265-272.

Okumura, J.; Tanaka, H. and Muramatsu, T. (1979): Incorporation of $\mathrm{N}^{15}$-urea in chicks. J. Poul. Sci., 16: 45-48. Patton, C. T. and Crouch, S. R. (1977): Anal. Chem., 49: $462-469$

Perry, T. W.; Baeson, W. M. and Mohler, M. T. (1976): A comparison of high urea supplements with natural protein supplements for growing and fattening beef cattle. J. Animal Sci., 26: 1234.

Pervaz, S.; Javed, M. T. and Pervaiz, S. (1993): Studies on feed consumption, feed conversion, live body weight and clinical signs in urea induced toxicity in broiler chicks. Singapore Vet. J., 17: 51 - 57.

Pervaz, S.; Javed, M. T.; Sabri, M. A. and Pervaiz, S. (1996): Hematological and biochemical findings in broilers fed different levels of urea. Pakistan Vet. J., 16 (2): 75 -77

Siller, W. G. (1981): Renal pathology of the fowl. A review. Avian Pathol., 10: 187-262.

Swift, R. W.; Thacker, E. J.; Black, A.; Bratzler, J. W. and James, W. H. (1947): Digestibility of rations for ruminants as affected by proportions of nutrients. J. Animal Sci., 6: 432-444.

Sykes, A. H. (1971): Formation and composition of urine. In: Physiology and Biochemistry of the fowl. D. J. Bell and B. M. Freeman (eds.). Academic Press (London, New York), pp. 233-278.

Thomson, R. G. (1984): General Vet. Pathol. W B. Saunders Co., Philadelphia.

Trinder. P. (1969): Ann. Clin. Biochem., 6: 24.

Visek, W. J. (1972): Effects of urea hydrolysis on cell-life span and metabolism. Fed. Proc., 31:1178-1193.

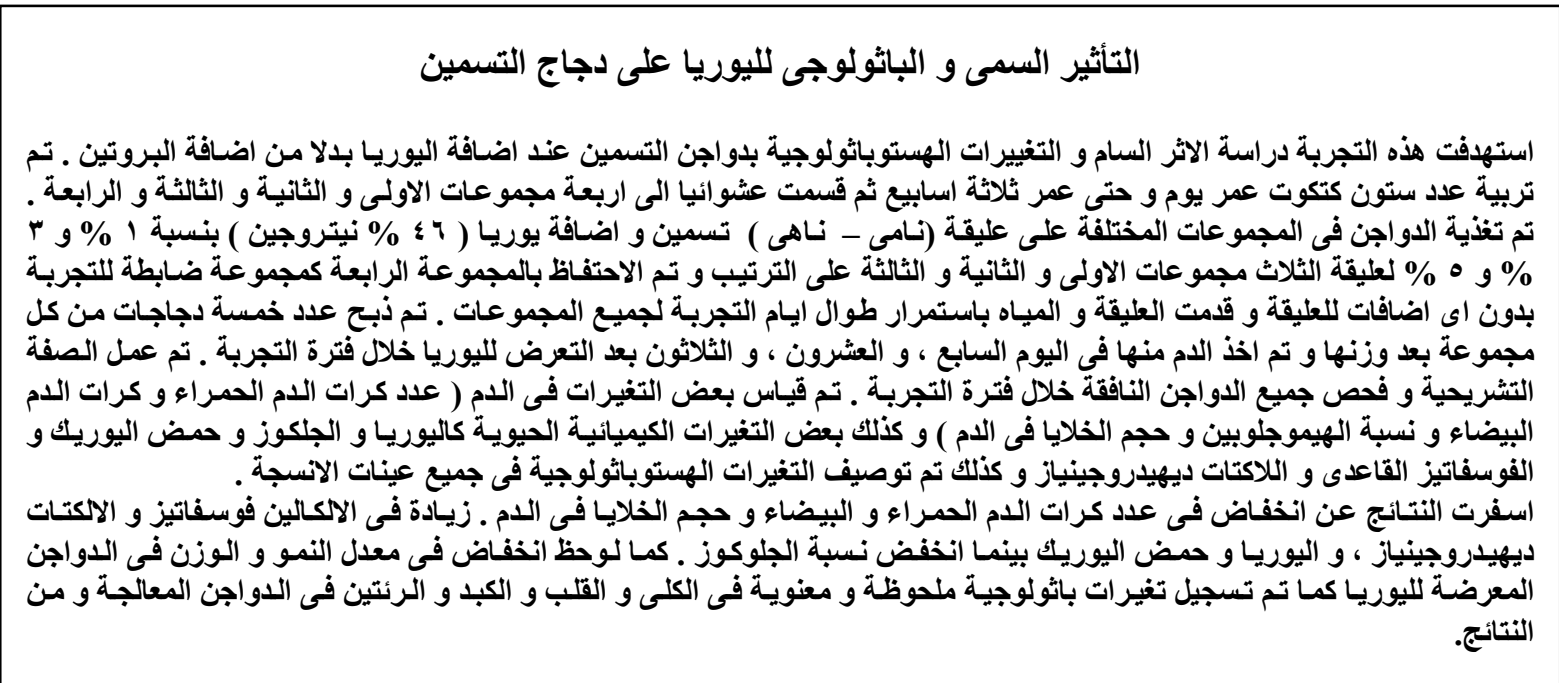

